This is an electronic reprint of the original article. This reprint may differ from the original in pagination and typographic detail.

Author(s): Dlaske, Kati

Title: Shaping subjects of globalisation : at the intersection of voluntourism and the new economy

Year: $\quad 2016$

Version:

Please cite the original version:

Dlaske, K. (2016). Shaping subjects of globalisation : at the intersection of voluntourism and the new economy. Multilingua : Journal of Cross-Cultural and Interlanguage Communication, 35(4), 415-440. https://doi.org/10.1515/multi-20150002

All material supplied via JYX is protected by copyright and other intellectual property rights, and duplication or sale of all or part of any of the repository collections is not permitted, except that material may be duplicated by you for your research use or educational purposes in electronic or print form. You must obtain permission for any other use. Electronic or print copies may not be offered, whether for sale or otherwise to anyone who is not an authorised user. 


\title{
Kati Dlaske*
}

\section{Shaping subjects of globalisation: at the intersection of voluntourism and the new economy}

\author{
DOI 10.1515/multi-2015-0002
}

Abstract: Volunteer tourism is one of the latest branches of the ever expanding globalised tourism. The initiative Workaway, an expression of this trend, was established in the late 90s with the aim of promoting "cultural understanding between different peoples and lands throughout the world". The figure of the workawayer as a new cosmopolitan subjectivity started to take shape. With the growth of the tourism industry, the Workaway scheme has started to be of interest also to tourism entrepreneurs, especially in the global peripheries such as northern Lapland, home to the indigenous minority language community of the Sámi. By signing up as a volunteer in a heritage tourism resort, the workawayer, the cultural adventurer, becomes linked up to the network of the globalised new economy. Drawing on aspects of governmentality studies, discourse studies and ethnographic approaches, this study traces the translocal formation of the figure of the workawayer through two crucial technologies of subjectification: the Internet portal workaway.info and the actuality of everyday work in a Sámi heritage tourist resort in northernmost Finnish Lapland. Although the Workaway initiative positions itself as non-capitalist if not anti-capitalist, the study shows how the workawayer is gradually shaped to meet the requirements of the contemporary neoliberal world of work. If Workaway offers new languages and cultures with a flavour of romanticised multiculturalism, in the tourist resort actual encounters are governed by straightforward market rationality. Here, languages are valued as skills among others, but not above others, since ultimately “you don't necessarily need any language for money transactions".

Keywords: volunteer tourism, globalisation, governmentality, discourse studies

\section{Introduction}

The contemporary era of globalisation is often characterised by the tropes of mobility and flows. In this image, people - tourists, workers and migrants -

*Corresponding author: Kati Dlaske, Department of Languages, University of Jyväskylä, Jyvaskyla, Finland, E-mail: kati.dlaske@jyu.fi 
goods and ideas circulate around the globe at an unprecedented pace, facilitated more recently by the Internet - a technology of globalisation par excellence (e.g. Appadurai 1996; Urry 2007; Coupland 2010). Much of this development emanates from the growth and diversification of the tourism industry over the past decades (cf. Urry 2007). While the growth manifests itself not only in the numbers of people travelling but also in the expansion of the industry ever further into global peripheries, the diversification shows in the trend of turning away from ready-made package tours towards individualised experiences, authenticity and alternative ways of travelling (cf. Uriely 2005). The increasing popularity of working holiday tourism, and of volunteer tourism - or voluntourism - as one of its most recent branches, is a clear expression of this trend. Working holiday tourism is a mode of travelling which combines work and holiday, thus enabling travellers to get better acquainted with life in the host country (Clarke 2004a; Duncan 2008; Tomazos and Butler 2009). One of the many current schemes offering this possibility is Workaway, an initiative set up in the late 1990's for promoting "cultural understanding between different peoples and lands throughout the world" (www.workaway.info).

The region of Lapland, which spreads over the northernmost parts of Scandinavia and Russia, is one of the globally peripheral regions currently experiencing the growth of tourism. Here, as in many other 'peripheral' areas, the expansion of the tourism industry is linked to structural changes symptomatic of contemporary late capitalism (cf. Heller and Duchêne 2012; Pujolar and Jones 2012; Heller et al. 2014). The expanding market for heritage tourism in Lapland is opening up new sources of livelihood, especially for the indigenous minority language community of the Sámi. However, although attracting increasing numbers of tourists, this peripheral region has failed to attract a permanent workforce from the southern parts of the countries in which it is situated. It is at this point that the need of tourism entrepreneurs for workers and the desire of working holiday-makers to explore remote destinations and learn about other cultures meet. And it is through this connection that the workawayer, the cultural adventurer, gets linked up to the network of the globalised new economy.

Research on working holiday-makers has focused on the one hand on the implications of the growing segment of working tourists for the local tourism industries (e.g. Duncan 2008; Jarvis and Peel 2013; Ruhanen 2010). On the other hand, the more sociologically oriented strand has engaged with questions of the regulation and formation of freedom and agency of working holiday-makers (e.g. Clarke 2004a, 2004b; Haverig and Roberts 2011). Although also research focusing more specifically on volunteer tourism has mainly been concerned with the cultivation of the trend as a segment of the tourism industry (Brown 2005; Brown and Morrison 2003; Coghlan 2006), some studies have taken a critical 
look at the increasing commercialisation of the tradition of philanthropic travel (Tomazos and Cooper 2012). On a broader plane, the growing trend of volunteer tourism ties in with the expansion of volunteer work outside the context of tourism. With neoliberalism, an increasing number of social services have been allocated to the 'third sector' (e.g. NGOs) or otherwise reorganised to make use of volunteer work (e.g. Baines 2004; Maes 2012). As Baines (2004) points out in her study, in the neoliberal order of work, volunteer work constitutes not only a form of work in its own right but also an extension of paid work in the form of unpaid internships, extra shifts and overtime, which accompany people throughout their working careers. In this connection, critical studies (e.g. Baines 2004; Maes 2012) have interrogated the ways in which these rearrangements produce and operate on new forms of exploitation, e.g. exploitation of the precarious working conditions and the altruistic orientation of unwaged workers, as well as the structural gender bias inscribed in these processes - aspects relevant also for the present study.

The present study addresses the question of the subjectification of working holiday-makers in the intersection of voluntourism and the new economy. More specifically, combining aspects from governmentality studies, discourse studies and ethnographic approaches, the paper investigates the translocal 'languaging' (see Dlaske et al., 2015) of the workawayer, in other words, how the workawayer is called into being through discursive practices involved in two crucial technologies of governance: the Internet portal Workaway.info and the reality of everyday work in a tourist resort run by a Sámi artist and entrepreneur in the far north of Lapland.

Although the Workaway initiative positions itself as non-capitalist if not anti-capitalist, the study shows how the workawayer gradually gets languaged into a self-responsible, freely choosing, enterprising self, geared towards the requirements of the contemporary neoliberalised world of work. While Workaway offers new languages and cultures with a whiff of romanticised multiculturalism, actual encounters in the tourist resort are governed by straightforward market rationality. If Workaway envisions multilingualism as a key to promoting cultural understanding throughout the world, in the tourist resort languages are valued as just one among the many skills needed for running a business.

In what follows, I will first present the two sites of investigation and then the analytical approach of the study. After this, the analysis follows the trajectory of a workawayer from preparing for a Workaway exchange through the Workaway portal, to the actual work site, the tourist resort in Lapland, and then back again to the website for retrospective feedback. In conclusion, the paper discusses the broader implications of the interconnection of voluntourism and the new economy in contemporary globalisation. 


\section{The two sites of investigation: Workaway.info and a tourist resort in northernmost Lapland}

\subsection{What is Workaway?}

Workaway is a scheme designed to enable people with limited financial resources to travel around the world and to gain deeper insight into other cultures than one gets on ordinary holiday trips. The Workaway scheme is based on volunteering: the workawayer works a couple of hours a day for a host who in exchange provides him or her with food and lodging (Workaway Home, no date). As such, the Workaway initiative positions itself as a part of the growing trend of volunteer tourism, or voluntourism, a mode of travelling which promises both at least a partial way out of the capitalist logic of monetary exchange and a chance to help others while enjoying a unique and memorable holiday. In 2008 the number of travellers participating in voluntary tourism schemes was estimated to have reached up to 1.6 million per year and the numbers are still growing (TRAM 2008; Tomazos and Cooper 2012). However, volunteer tourism schemes vary in the principles on which they operate: while some operate like package tour providers, organising the whole trip and charging accordingly (cf. Tomazos and Cooper 2012), others, like Workaway, as we will see below, only offer a loose framework, providing first and foremost a virtual platform for prospective hosts and volunteers to establish contact.

The website Workaway.info is the virtual platform of the Workaway initiative. On this site, organisations and individuals willing to act as a host can create a profile in which they introduce themselves, describe the kind of work they are offering and provide any additional information that might be useful for prospective volunteers looking for a place to go. Currently, would-be workawayers can browse the profiles of hosts from over 130 countries in Europe, Asia, North America, South America, Africa and Oceania. Typically, the work on offer includes gardening, farming, helping on an eco project, child care, animal care and helping with tourists (Workaway hostlist, no date). Once the prospective workawayer has found a host that he or she considers to be promising, he or she contacts the host. To be able to do this, the would-be volunteer needs to register on the site and pay a fee of 22 euros, which is valid for two years. Upon registration, the prospective volunteer in turn sets up a profile. Once the workawayer has contacted the host, the host can see the workawayer's profile. All further arrangements for a Workaway exchange have to be made directly between the host and the workawayer. It is up to the hosts to decide whether they want the candidate or not. 
Besides the possibility of setting up a profile, the website provides general information about the Workaway initiative, advertises its benefits, showcases selected Workaway stories through written reports and short video clips, and provides more specific information for prospective hosts, workawayers and language learners, each on their own subpages. The subsection dedicated to "language learners" advertises the advantages of a Workaway exchange vis-ávis language courses organized by language travel agencies and formal classroom learning, the main benefits being lower costs and learning through "immersion", respectively. Through this additional emphasis, the Workaway scheme sets itself in competition not only with ordinary holiday tour operators but also with language travel agencies. These contents, like the host profiles, are available to everyone visiting the portal. The only thing 'private' are the profiles of prospective volunteers, which are accessible only to the hosts the volunteers have chosen to contact. Although the main page advertises "volunteers come from all sorts of backgrounds", the images and stories suggest that workawayers are mostly of 'Western' origin and youngish. Also the languages in which the Workaway.info portal exists, English, German, Spanish, and more recently, French, indicate an orientation to the 'Western market' or at least presuppose a reader literate in (at least) one of those four languages. Besides the contents described above, the website features a section advertising the possibility of buying a Workaway subscription as a gift. This, along with the frequent references to the low costs of this mode of travelling, indicates that the Workaway scheme is targeted especially, as it is put on the website, at "people traveling on a limited budget". In the following analysis, we will focus on pages from the site that bear particular relevance to the question of the subjectification of workawayers. From the four languages, the analysis draws on the English version. First, however, let us turn to the ethnographic site of the study.

\subsection{In a centre in the periphery}

While most of the volunteer work offered through the Workaway scheme is in non-profit settings (e.g. in families or charity projects), a growing number of offers are in a commercial context, mostly in tourist resorts. One such context is the tourist site in the focus of this study, located in northernmost Lapland, three hundred kilometres inside the Arctic Circle. More specifically, the site is located in a village which is traditionally the political and cultural centre of the indigenous language minority Sámi people in Finland. Nowadays the village is, moreover, a growing centre for tourism built on the cultural heritage of the 
Sámi. While there are several options for accommodation and tourist activities in this small but lively village, in this paper we will focus on the guesthouse and the tourist activities of a particularly entrepreneurial and innovative Sámi woman, whom we will here call Pia. Besides being a tourist entrepreneur, Pia is a talented craftswoman and artist who makes traditional Sámi handicrafts, designs and produces more modern variations of these, and paints pictures inspired by her Sámi heritage, which she also occasionally showcases in painting exhibitions, e.g. in galleries in Helsinki (see Dlaske 2014). Pia comes from the north of Lapland, but has lived several years abroad, including in France and Spain. She still travels a lot and still spends some weeks every year in Spain (cf. Kauppinen 2014; Dlaske 2014). She moved to the village in the beginning of the 2000's to set up her own tourism business which today comprises, besides two small guesthouses and two handicraft shops, various tourist activities, such as snow tours with her horses and excursions to see the northern lights. One of the guesthouses and the handicraft shops are located in the village in the focus of this study. As the business grew, Pia came increasingly to need additional help. However, as she explains to me, few people from southern Finland were willing to move to northern Lapland to work in a tourist resort. In the spring of 2012 she came across the Workaway initiative and decided to set up a host profile on Workaway.info. At around the same time there were a number of other tourism entrepreneurs in Lapland who saw a chance in the possibilities offered by the Workaway scheme and started to show up as host candidates on the Workaway site. Ever since Pia set up her host profile on the Workaway site, she has had some three to seven workawayers at a time helping out with her guesthouse, shop, horses and tourist activities. The volunteers have come from different parts of the world including Germany, Spain, France, the UK, the United States, Australia and Colombia. Most of them are 20-something women on a gap year or semester break, similarly to typical volunteer workers worldwide (TRAM 2008), but there are also older volunteers, people who have decided it is time to do something else with their lives. Some volunteers stay for a couple of weeks, others for several months. For many the stay at Pia's tourist resort is just one in a chain of stays at different Workaway hosts - a chain which provides them with a way to travel across the world.

The ethnographic data of this study, gathered as part of a larger discourse analytical ethnographic research project, ${ }^{1}$ comes from this tourist resort. It has been collected on altogether seven intensive fieldwork trips over a period of

1 The study is part of a larger research project, conducted within the framework of the Peripheral Multilingualism project (2011-2015), funded by the Academy of Finland. 
two years (2011-2013). The data comprises interviews with Pia and five of her workawayers (four female, one male), informal conversations with Pia and many of her volunteers, and field notes from my stays. During the fieldwork trips I stayed in Pia's guesthouse, which gave me the opportunity for ongoing observation and informal discussions with both Pia and the volunteers. The volunteers with whom I carried out the interviews were "Steffi", "Anna", "Martha", "Katharina" and "Jim". Steffi and Anna came from Germany, Martha came from Holland, Katharina from Hungary and Jim from England. Like most of Pia's volunteers, the female participants were students in their twenties who had discovered in the Workaway scheme an opportunity, as Martha put it, "to do something cool and to travel to see more of the world." Jim, on the other hand, was a carpenter already in his forties. Like the younger female participants, however, he too had wanted to do something different in his life and decided to sign up as a volunteer. For all of them, Pia's tourist resort was not the first place where they had stayed, but they had been working in different parts of the world both as volunteers and for money, taking care of children and helping out in hotels and other small businesses. The interviews with Katharina and Jim were carried out on site and audio recorded; the interviews with Anna and Martha were done by email. With Steffi I had two interviews, one on site and audio recorded and another that was done by email. The interviews with Steffi and Anna were conducted in German, the others in English.

\section{The analytical approach}

To investigate how the workawayer is called into being as a subject (Foucault 1982) by drawing on the data presented above, the study combines aspects from governmentality studies (e.g. Rose 1996; Bröckling et al. 2000) and approaches in discourse studies, which view discourse - language use - as a multimodal social practice, understanding 'practice' - or 'practices' - as bundled sets of repeated actions (e.g. Pennycook 2010; Blommaert 2005; Scollon 2005; Scollon and Scollon 2004).

Drawing on the perspective of governmentality studies, the present study distinguishes three dimensions: rationalities, technologies and subject effects (Bröckling et al. 2000: 22; Rose 1996: 152-153; Dlaske et al., this volume). While 'rationalities' can be understood as particular kinds of logics of government, 'technologies' may be thought of as "diverse and heterogeneous means, mechanisms and instruments" (Dean 2010: 269) which enable a "calculated orchestration of the activities of humans under a practical rationality directed 
toward certain goals" (Rose 1996: 153). Recalibrating the view of much of the governmentality literature which, following Foucault, operates on a distinction between technologies and (self-)techniques (e.g. Rose 1996; Bröckling et al. 2000), the present study is based on the notion that the technologies of subjectification operate through a variety of (discursive) practices, which makes it possible to adjust the analytical focus to the micro level of language use. This being the case, in the present study, the 'technologies of subjectification' form an intermediate link between "the calculated orchestration of the activities of humans", i.e. practices of (self-)government, and particular rationalities and, further, broader governmentalities. Thus, the perspective of governmentality studies in combination with the 'practices approach' of discourse studies provides a particularly fruitful angle on voluntourism. Besides enabling a detailed examination of the ways in which humans are called into being simultaneously as workers, multilingual language users, and subjects of movement and social change (cf. Dlaske et al., this volume), it makes it possible to explore how these practices tie in with the governmentalities of both the new economy and, more broadly, of neoliberalism, which is characterised by globalised market rationalities that enter into competition not only with other logics of (self-)governance, but also with the interests of states (cf. Dlaske et al. this volume).

Following the framework outlined above, the analytical procedure involved first distinguishing smaller technologies of subjectification from the two main technologies, the Internet portal Workaway.info and the actuality of everyday work in the tourist resort presented above. The technologies identified, which in the following also structure the analysis, include: (1) getting attuned to the Workaway ethos, (2) preparing for a Workaway exchange, (3) working hours on the site, (4) skills required in the job (cf. Urciuoli 2008), (5) the host's expectations, and (6) giving and receiving feedback after the exchange. The second phase included an investigation of the discursive practices through which these technologies operate. While these practices may be more linguistic or more material in their nature, they are discursive in that they are mediated through knowledge (Foucault 1981; Blommaert 2005: 3; Scollon 2005). In the third phase, attention was directed to the attitudes, values and qualities the workawayer becomes geared to through these technologies and practices, in other words, to the subject effects they seek to evoke. In the fourth and final phase, an answer was sought to the question: What rationalities underlie these technologies, practices and subject effects and to what larger societal developments are they connected?

In the following investigation, we follow the trajectory of a workawayer from his or her first becoming acquainted with the Workaway scheme and preparing for a Workaway exchange via the website Workaway.info to the tourist resort, continuing there with an examination of the actuality of everyday work there. In conclusion, we return to the website to analyse the practices of giving feedback on the Workaway experience. 


\section{Shaping subjects of globalisation: following the trajectory of a workawayer}

\subsection{Becoming attuned to the Workaway ethos}

The technology I have labelled 'Becoming attuned to the Workaway ethos' operates through attractive and enticing descriptions of the Workaway scheme: its 'philosophy', aims and operating principles. Essentially, this is done directly on the opening page, entitled "Workaway Home" (Workaway Home, no date). In addition to its description of the philosophy and aims of the initiative, the page features a list of the countries most searched on the site, a few examples of host announcements, and two links leading to Workaway feedback. The page also displays an advert for a website promising to give "excellent travel tips and insights into staying safe whilst travelling" along with another advert urging “Travel insurance. Don't ignore it!”

On the top of the page, a caption entices the reader:

Work abroad, integrate in local cultures, learn a language, acquire new skills, make new friends through ... Workaway.info. The site for travel, language and work exchange.

Below the caption the page displays a world map and below this the description:

Workaway.info is a site set up to promote fair exchange between budget travellers, language learners or culture seekers and families, individuals or organiations who are looking for help with a range of varied and interesting activities.

Our philosophy is simple:

A few hours honest help per day in exchange for food and accommodation and an opportunity to learn about the local lifestyle and community, with friendly hosts in varying situations and surroundings.

Our aims are:

- $\quad$ To promote cultural understanding between different peoples and lands throughout the world.

- To enable people travelling on a limited budget to fully appreciate living and working in a foreign environment.

- To promote the exchange between people from different nationalities, and give a chance for volunteers to contribute to a cause.

- To enable language learners to experience different countries and immerse themselves in their target language whilst living abroad.

- To give opportunity to projects around the world to receive support form skilled volunteers and have a real and immediate impact on their projects 
In this outline, the operators not only explicitly state the aims and philosophy of the Workaway scheme but also offer a number of rationales for embarking on a Workaway exchange, including the possibility of working abroad, integrating into local cultures, learning a language, acquiring new skills, making friends, and contributing to a worthwhile cause. Beyond these concrete opportunities, the emphasis of the initiative, as reiterated in a number of ways, is on enhancing "cultural understanding between different peoples and lands throughout the world". The Workaway initiative also subscribes to the values of honesty, friendliness and fairness, the last one manifesting itself not only in the emphasis on "fair exchange", but also in the effort to support "people with limited budget”. While the workawayer is defined as a "budget traveller", "language learner" and/or "culture seeker", the host is described as being a family, individual or organisation. Thus not only is the exchange between the hosts and the volunteers nonfinancial in its nature, but the envisioned parties are emphatically non-profit entities and the rationale of work, as suggested in the description, is the opportunity to "contribute to a cause". Essentially, then, when entering the world of Workaway through this opening page, the potential workawayer becomes attuned to the ethos of a kind of non-capitalist cosmopolitan humanism in which language(s) figures as the key to achieving "cultural understanding between peoples and lands” (cf. Harvey 2009; see also Motobayashi, this volume).

\subsection{Preparing for a Workaway exchange}

Embarking on a Workaway exchange requires, however, more than the wish to integrate into local cultures and to contribute to a good cause. It involves making a number of arrangements in advance wherein the initiative and responsibility lies with the would-be workawayers. This preparation works as another technology of subjectification, which involves besides tips and instructions for getting prepared also actual action on the part of prospective workawayers. Crucial for mediating these practices are the pages entitled "Information for Workawayers" and "Safety" as well as the search machine for searching for a suitable host. In the following, we will investigate each of these in turn.

On the page "Information for workawayers" (Workaway Information for travelers, no date), after first laying out once more the plentiful opportunities offered by a Workaway exchange, the operators of the initiative go on to point out:

Remember though, Workaway.info is not an agency. We enable you to find placements. It is up to you to write yourself a great profile, to make the contact, to introduce yourselves with an e-mail, to organize your travel arrangements, to arrange your travel visas, and to discuss directly with your host the ways in which you can volunteer and help. 
Once you've signed up, as well as being able to contact hosts, you will be searchable as a volunteer by the hosts on the site. Hosts often look for volunteers with specific skills such a certain language or practical skill. You will be able to fill in a brief profile about yourself and what you can offer.

Despite the emphasis on cultural exchange, Workaway is about work, and the measures the prospective workawayer has to take to find a host are virtually the same as those involved in a job application process. Thus, through his or her efforts to find a place to stay, the workawayer gets trained too in recognising and marketing his/her (particular) skills and writing a great profile of him/herself to attract possible hosts/employers, as well as in contacting a host/employer, introducing him/herself in an e-mail and discussing with the host what the work might involve - all skills required from active and capable job seekers in the contemporary working life (cf. Urciuoli 2008; Rose 1996; Bröckling 2005, 2007; Inoue 2007). The process of organising one's travel arrangements and a visa provides training not only in practices involved in global travelling but also in mental capacities such as planning, organisational skills and - not least - courage.

After the instructions presented above, there follows a list of frequently asked questions. Here, the prospective workawayer finds questions and answers on practical matters such as how to register with Workaway.info and what this costs, and what will be expected of them. From the answer to the question "How long am I expected to work for?" the potential volunteer learns that "the standard Workaway volunteer rate is $5 \mathrm{~h}$ per day 5 days a week in exchange for food and board", but that this also is, "of course [-] negotiable with your hosts upon your arrival." Furthermore, the prospective workawayer learns that there is no minimum time s/he must stay for and that the maximum time "depends on the work [the] host is willing to offer". The notion that the workawayer is expected to take the "work the host is willing to offer" has prompted the question whether there are any jobs the workawayer should refuse to do. Again, the answer is to discuss this in advance with the host, complemented, however, with the general advice not to "attempt anything that is obviously dangerous or should be carried out by a qualified professional". The assessment of what seems "obviously dangerous" or like a job for a qualified professional is, however, left openand the responsibility lies with the traveller.

The question about possible risks ties in directly with the theme of the page entitled "Safety" (Workaway Safety, no date). As the name indicates, the page addresses issues relating to safety and possible risks during a Workaway exchange. A crucial part of becoming a workawayer is the willingness to take on the risks involved in travelling alone to a "completely alien environment" and staying in the home of people one does not know. Hence, ultimately, as emphasised in the opening paragraph of the page, "workaway works on trust", 
the writers hold, just as "any interaction we have with other humans depends on trust”. However, overcoming one's fears with the help of trust in one's fellow human beings turns out to be not quite enough. It is equally important, as the next paragraph, entitled "Precautions", hastens to add, "not to take unnecessary risks" such as giving out one's personal details, e-mail address or phone number until, the writers advise, "you feel that the contact seems like the kind of person you would be interested in hearing from" (italics mine). In addition to this personal assessment, as further risk management measures the would-be workawayer is advised to investigate

your planned destinations beforehand and cue yourself on any recommended precautionary measures of the place in question, whether this be immunisation programmes, political trouble-spots, what is considered culturally unacceptable or risky ... and places which are considered to be popular hang-outs for pickpockets etc. If you are travelling alone, especially if you are a woman, you may have to give more consideration to how/where/when to travel.

In addition to these "precautions" the prospective workawayer is advised to clarify the work, sleep and eating arrangements with the host prior to the trip. The advice is followed up with the remark: "If you are uncomfortable about the volunteer conditions, then it is up to you to back out and to say no".

Pursuing further the question of possible risks, the last section of the page concerns "general internet safety advice". Despite the tone of optimistic humanism and trust in fellow human beings expressed in the opening paragraph, the writers remind the reader here that "it is always important to be aware of people who could be dishonest", and they advise the workawayer to inform him/herself about common scams in order to be able to spot and avoid these in time. Thus, if becoming a workawayer requires a willingness to embrace risk and set out on an adventure sustained by an essentially humanist outlook on life with faith in other people it also includes (training in) long-term risk management based on a recognition that ultimately one has to accept responsibility for one's own life.

Once the would-be workawayer has acquainted him or herself with the practical arrangements and considerations involved in a Workaway exchange, it is time to choose a host. To find a suitable host, prospective workawayers can browse the host profiles by continent, country and region, or by type of work. As mentioned above, currently volunteers can search for a host in over 130 countries, on all continents except for Antarctica. If the practices of writing a profile of oneself, contacting the host, and agreeing with him or her on the work tasks bear comparison with a job application process, as suggested above, then finding a suitable host makes the first link in this chain. The procedure of choosing the host represents an exercise in self-reflection in and of itself, driven by the questions Where do I want to go? What do I want to do? What am I good 
at? This trains volunteers in the skill of knowing oneself - a core requirement in the contemporary neoliberal order based on the notion of freely choosing individuals (Bröckling 2007; Kauppinen 2012). This notion is, however, also at the heart of the Workaway scheme: in declaring encouragingly that "the possibilities for exchanges are endless" (Workaway Information for travellers, no date) the operators of the scheme explicitly posit the prospective workawayer as a freely choosing subject in the global (job)market place. The cosmopolitan orientation towards other countries, cultures and languages evoked on the opening page of the site (see Section 4.1, above) takes on a decisively different ethos - that of neoliberal consumerism (cf. Motobayashi, this volume).

Besides the wishes of the workawayer him or herself, of crucial importance in the decision that will finally be made are the host profiles, the 'job announcements' of the volunteer job market, which create a horizon of expectations for volunteers. The host profile of the Sámi artist and entrepreneur, Pia, who was introduced above, does this as follows: ${ }^{2}$

I am a Sami artist, traditionally working with textiles. I run a guesthouse and giftshop. Much of my artwork is in exibitions all over the world. I use my Sami culture in my artwork, working with traditional symbols and myths, but expressing them in a modern way. I do not have children, but I love animals. I am a modern nomad, with a house in Spain. I have studied in the United States, France, and I travel a lot. I enjoy cooking and good food. [-]

I am looking for volunteers who will help me in the shop, helping with handicrafts, working in the guesthouse with breakfast, cleaning rooms, and general work such as laundry and shoveling snow.

[Name of the village] is the center for finnish samis and very well known for traditional

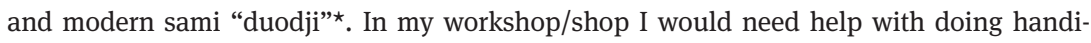
crafts from leather and fabriks. People staying with me can really learn about the modern sami culture and by doing learning about the old and new handicraft skills.

I also try to bring some old stories and legends in to the this times needs so work is also designing and planing new products. That can be helpful skil for many who plan to do something them selfs later.I have only 5 rooms in my little guesthouse and now going to chanege the interior design to show sami culture in modern contest. So, during the autum 2013 I would need help with creating that too. [-] If you have some basic skills in arts and crafts you can learn many new skills of doing with hands with me. If you are very skilled in hadicrafts you can find totally a new are of materials and methods of art and quality handicrafts. Staying in [name of the village] is also learning about the local food culture. [-] Working hours vary, but are generally around 2-5 hours per day.

*’Duodji' is a Sámi word for traditional Sámi handicraft (see Dlaske 2014).

After this description, there are a number of photos showcasing handicraft items made or designed by Pia herself and one showing her hugging one of her horses.

2 The description is quoted here exactly as presented on the website. 
The description finds clear resonance with the philosophy and aims put forward by Workaway. Although Pia mentions the commercial context - the guesthouse and the gift shop - and briefly outlines the work relating to these, the main emphasis is on culture and artistic creation. As well as introducing herself as a Sámi artist and placing her work in the Sámi artistic and cultural tradition, she highlights that the village in which the guesthouse is located is the centre for the Sámi in Finland. While describing the tasks related to handicraft making (e.g. "help with doing handicrafts" and "designing and planning new products"), she takes care to emphasise the aspect of learning about Sámi culture and acquiring new handicraft and design skills, which makes the description connect directly with the aims and goals of the Workaway initiative discussed above ("promoting cultural understanding between peoples", "integrating in local cultures", "learning new skills").

Although Sámi culture and a creative, artistic atmosphere form a crucial dimension of the guesthouse and gift shop, both are fundamentally part of the growing tourism industry in Lapland. As will become evident in the following investigation of the reality of everyday work in the tourist resort, it is essentially the rationality of business that shapes the practices and the figure of the workawayer there, regardless of what is said in the description. To examine these processes in more detail, we will focus in the following on three further crucial technologies of subjectification, namely working hours on site, the skills required in the job, and the host's expectations.

\subsection{Working hours on site}

Pia's guesthouse is a red wooden building located along the only main road leading through the village. On the ground floor there is a cafeteria in which guests can enjoy breakfast. The handicraft shop, also a little red house, is located next to the guesthouse. It is packed with colourful handicraft items of Pia's making and design: jewellery, ceramics, home decoration items, bags, clothes and more (see Dlaske 2014; Dlaske 2015). Despite the abundance of crafts in the shop and the emphasis in the host profile on artistic work and handicrafts, the volunteers' main tasks relate to running the guesthouse and the handicraft shop, including checking guests in and out, preparing breakfast, cleaning the rooms, and selling craft items. It is perhaps not surprising, then, that the working hours, mentioned in the host profile as being "generally around $2-5 \mathrm{~h}$ per day", turn out to be rather different. Anna's description of her typical day corresponds well with what I observed during my stays in the guesthouse: 
Ich bin früh aufgestanden und fing meistens um 7.30 an $\mathrm{zu}$ arbeiten. Ich habe das Frühstück für die Gäste gemacht und mich um den Check out gekümmert. Danach habe ich die Zimmer gereinigt. Dann, wenn noch Zeit für eine Mittagspause war, habe ich etwas gegessen und dann ging es ca. um 11 Uhr in den Laden von [Pia]. Dort habe ich dann bis 18 Uhr verkauft und ab und zu den Check in fürs Gästehaus gemacht.

I woke up early and started to work mostly around 7.30. I prepared breakfast for the guests and took care of the check-out. After that I cleaned the rooms. Then, if there was time for a lunch break, I ate something and then went around 11 o'clock to [Pia's] shop. There I kept selling till 6 p.m., every once in a while doing a check-out from the guesthouse.

One specialty of the guesthouse is the fresh home-made bread they serve at breakfast, baked according to Pia's 'secret recipe'. Baking the bread is also one of the volunteers' duties. The bread takes one hour to bake and the dough needs to be prepared the evening before. For the volunteers this means preparing the dough late in the evening, after they have completed their other tasks, and waking up early in the morning to get it in the oven. Since it is supposed to be the highlight of the breakfast, the bread is baked even if there is only one guest.

Another special feature of the guesthouse is that it does not have any latest time for check-in, but guests are welcome to arrive at virtually any time without any advance warning. At the guesthouse, there is a telephone number at the door which guests can call if there is no one around when they arrive. Consequently, occasionally, volunteers are called on to check someone in after they have already gone to bed. Through these practices working hours tend to be not only long but also unpredictable, requiring volunteers to respond flexibly to the situation. The guiding principles regulating working hours are not only market forces, but a radicalised version of the customer orientation characteristic of the contemporary new economy, and epitomised by the notion, as one of the volunteers succinctly put it, that the customer is king (cf. Voswinkel 2004; Barakos and Motobayashi, this volume).

The number of volunteers working at the guesthouse varies, but the business has to be kept running at all times. When there are fewer workers, those who are there have more to do. Anna, who stayed altogether three weeks, working partly in the guesthouse and partly on the farm with Pia's horses, recalls further

Frei sollte ich planmäßig nicht haben (So sah es [Pias] Plan vor, den sie für uns vorbereitet hatte. [-]). Allerdings habe ich zwei Mal einen Tag frei gehabt. Und wenn ich auf der Farm gearbeitet habe, hatte ich nachmittags frei.

According to the plan, I wasn't supposed to have any free days (That's how [Pia's] plan had it which she had prepared for us. [-]). Twice, however, I had a day off. And when I was working on the farm, the afternoons were free. 
Business rationality is, however, not the only factor regulating the volunteers' working hours. Another turned out to be the peripheral location of the tourist resort in the small village in the North of Lapland. As both the host and some of the workawayers themselves maintained in our conversations, in fact they did not even want to have days off as there was not much to do in the village if they did have any spare time. Working overtime thus became a choice made by the workawayers themselves. The notion of not wanting to have free days represents but one dimension of a larger whole: indeed, the same logic of apparently free choice governs the whole notion of volunteering. Moreover, as became evident in the examination of the Workaway portal above, there is no contract binding or regulating either party to the Workaway scheme and virtually every aspect of the stay is left open for negotiation. Hence, whatever the workawayer does as part of the stay is interpreted as being, by implication, of their own free will. Ultimately, as the host noted in an interview with me, if volunteers are not happy with their stay somewhere, they are free to leave. This being the case, these practices not only reproduce the logics of deregulation and individual responsibility characteristic of the neoliberal order of work, but effectively work through 'government through freedom', one of the cornerstones of neoliberal governmentality in general (cf. Rose 1999).

\subsection{Skills required in the job}

As the above examination has shown, both the Workaway initiative and Pia's host profile emphasise the aspect of learning new skills through the Workaway exchange. While the operators of the Workaway initiative do not specify these any further, in her host profile Pia highlights the opportunity she offers for the hands-on learning of old and new Sámi handicraft skills, the latter including also knowing how to plan and design new products. However, as the previous section indicates, most of the everyday work at the tourist resort involves quite other things than designing and doing handicrafts. Through their daily work routine, volunteers become trained in competencies such as the interactional and problem-solving skills needed in encounters with customers and taking care of financial transactions in both the guesthouse and the shop. What is more, as Pia travels a lot and is often away, the task of running the guesthouse and the shop is often largely left to the volunteers, who thereby learn by doing how to run such businesses. As regards the applicability of these skills and experiences, all of them are competences required globally in the growing tertiary sector (cf. Heller and Duchene 2012). As far as learning about Sámi culture and acquiring new handicraft skills are concerned, ultimately these are also incorporated 
into the practices and rationalities of the handicraft business, specifically in developing, designing and creating handicraft products for sale. Although the volunteers occasionally have the chance to develop and prepare handicrafts, this is less doing something with Pia, as the host profile description suggests, than doing according to her instructions while waiting for customers in the shop.

One central aspect of the Workaway initiative is language learning or, as the portal Workaway.info puts it, the opportunity to "learn a language" by "immersing oneself in the target language whilst living abroad" (Workaway home, no date). Although all the nine Sámi languages are classified as endangered (e.g. Pietikäinen and Dlaske 2013), three of them have the status of an official language in the village where Pia's guesthouse is. The language of everyday communication amongst the residents of the village is, however, for the most part Finnish. Another prominent language, the lingua franca amongst locals and tourists, is English. English is also the common language at Pia's tourist resort, both in communication with tourists and amongst the workawayers with their diverse backgrounds. The English the volunteers learn in their everyday work is, as regards vocabulary and idioms, the English used in the service sector all around the world. The language skills the volunteers acquire during their stay thus add yet another competence which meets the requirements of globalised (tertiary sector) business.

Despite this pedagogical dimension, the customer-oriented working practices make the workawayer at least as much a language worker as a language learner, and so also the aspect of language learning gives way to the rationality of the market. While learning about Sámi culture is at least partly compatible with the guesthouse and handicraft business, the notion of learning the local language fits into the picture less easily. In fact, in this context the romantic notion of immersion in the target language could take on a rather nightmarish aspect. Most of the tourists come from abroad - France, Germany, England, Japan - and have at least some proficiency in English, or the volunteers happen to know, because of their background, French, German or other languages the tourists speak. Occasionally, however, there are also Finnish or Sámi speaking customers who do not understand English. In most cases the volunteers do not speak Finnish. Although teaching her volunteers even some basic phrases in Finnish or Sámi would not only add "a layer of authenticity" (Torabian and Arai 2013, 11; see also Dlaske 2015) to encounters with tourists from abroad but also make communication possible with Finnish/Sámi speaking customers, Pia has not invested any of her time in this - in most cases the business gets done anyway. The following account given by Steffi describing her experience in the handicraft shop, illustrates vividly not only the aspect of language conflict which arises as a result of this but also the dominance of economic rationality in the daily (language) practices at the tourist resort. 
Und dann kommen Momente ... und man merkt genau die [Kunden] sprechen Finnisch und man denkt sich 'Na super. Du sprichst kein Finnisch. Das wird wieder ein Spa $\beta$... 'Und dann wird man auf Finnisch angesprochen und kann leider nicht sagen ... wie gesagt, ich kann's nicht mal auf Finnisch sagen, ich spreche kein Finnish, ich kann's nur auf Englisch. Und die die kein Englisch sprechen verstehen eben wahrscheinlich auch das nicht mal und wundern sich dann warum ich nichts sagen kann oder warum ich nichts sage [-]. Und von daher ist es für sie sicher auch unangenehm weil sie nicht wissen wie sie sich für mich verständigen können und für mich ist es natürlich extrem unangenehm, weil ich in Finnland bin, im finnischen Laden mit Sami Produkten und finnischen Handarbeiten und dann warten die Leute auch in gewissen Maßen das man Finnisch spricht. [-] Das kann eben wirklich unangenehm werden, wie zum Beispiel heute, wo ein in Sámi Kleidung gekleideter Mann kam, der mich auf Finnisch fragte, oder Samisch ... ich wei $\beta$ gar nicht was es war ... und ich konnte gar nicht antworten ... da war noch das Glück dass da jüngere Begleitung dabei war, die übersetzen konnte [-] Diese äußerst sympatische, aggressive ... was auch immer ... Sámi, ich weiß es nicht, was sie war ... Russin.. ich hab’ keine Ahnung, wirklich, der ich fünf Mal gesagt habe 'Ich spreche leider kein Finnisch', ich kann es nicht ändern. [-] Und so endete die Diskussion, ich meine, für Geldgeschäfte braucht man nicht unbedingt die Sprache, ne? Man zeigt die Zahl vom Taschenrechner, dann wei $\beta$ er auch ... [-] Klar möchte man sich verständigen, aber ... [-] Im Moment beschränkt es sich wirklich darauf, sie gibt mir die Ware, ich tippe den Preis ein, zeige ihr den Gesamtpreis, sie gibt das Geld rüber, ich wechsele und das war die Interaktion letztendlich.

And then there are moments ... and you realise yes they [the customers] are speaking Finnish and you think, 'Oh, great. You don't speak any Finnish. That's gonna be fun again ... 'And then they address you in Finnish and unfortunately you are not able to say ... as said, I cannot even say in Finnish that I don't speak Finnish, I can only say it in English. And those who don't speak English will probably not understand even that and ask themselves why I can't say anything or why I don't say anything [-]. And that's why it's certainly also awkward for them because they don't know how to communicate with me and for me it's of course extremely awkward because I'm in Finland in a Finnish shop with Sami products and Finnish handicrafts and then people kind of expect that you'd speak Finnish. [-] That can really get awkward, like today, when a man in a Sami outfit came in and asked me in Finnish or Sami ... I don't know what it was ... and I couldn't answer anything ... He was lucky to have this younger companion with him who was able to translate [-] This extemely sympathetic, aggressive ... whatever ... Sami, I don't know, she was ... Russian ... I really don't know, really, whom I told five times 'I'm sorry, I don't speak Finnish', I cannot change that. [-] And so the conversation stopped, I mean, you don't necessarily need any language for money transactions, right? You show the number on a pocket calculator, that's how he knows, too ... [-] Of course, you would like to be able to communicate, but ... [-] At the moment it's really limited to her giving me the product, I type the price, show her the total price, she gives me the money, I give the change and that was the interaction, ultimately.

At this point, Steffi has been staying in the tourist resort for a month. However, she is not able to communicate with customers in Finnish. In fact, as she emphasises, she is not even able to say in Finnish that she does not speak Finnish - which is considered by workawayers to be the basic sentence that 
everyone needs in Finnish and the ultimate survival resource with customers, as Steffi explains to me later on in the interview. This makes her feel ashamed and frustrated; she considers such situations extremely unpleasant, not only to herself but also, as she supposes, to the customers. She wants to be able to communicate but acknowledges with some resentment that 'business does not necessarily need language'. Her schematic, sequential demonstration of the interaction situation at the end of her description illustrates clearly the character of encounters like these, reduced to purely economic exchange. At the same time this somewhat ironic representation shows that she has internalised, if not any language skills, anyway the core practices of such economic encounters.

\subsection{Expectations of the host}

A third technology of subjectification which regulates the conduct of the workawayers in the tourist resort is the host's expectations with regard to her volunteer workers. When I ask Pia during one of our conversations what she expects from her volunteers, she replies instantly: "omatoimisuutta ja reippautta" ('independent initiative and alertness'). When I ask the workawayers what they think Pia expects from them, the answers follow surprisingly similar lines. "Sie erwartete sehr grosse Selbstständigkeit und Eigeninitiative" ('She expected very high self-reliance and independent initiative"), Anna replies. "Be responsible for your self”, replies Martha, a 19-year-old volunteer from Holland, in her answer via email, and notes further: "As work giver she was tuff because she wanted it to be done.and because she was traveling allot she dependet a bit one us, so we hadto take responsabillaty. That was not always nice if you just started there."3 Martha's answer also reveals the main reason why responsibility for oneself and independent initiative were so crucial at the tourist resort: Pia, indeed, travels a lot. When she is away, responsibility for running the tourist resort is left to the volunteers. And often they had to take this on, as Martha also implies, rather quickly. Anna too describes how she met Pia only at the beginning and end of her 3-week stay there; the rest of the time she had to find her way herself, guided only by other volunteers who already had more experience.

In these circumstances, the role of those who stayed longer became even more important, and what Pia expected from them also increased. In her response Steffi, who ended up staying several months at the resort, provides a whole list of the qualities she felt Pia expected from her and which in the course of her stay made her Pia's confidante: “Klugheit, Zuverlässigkeit, Zielstrebigkeit,

3 Also here, the description is quoted as Martha wrote it in her reply. 
Einsatzbereitschaft, Verantwortungsbewusstsein” ('cleverness, reliability, goalorientedness, readiness for action, a sense of responsibility'). While certainly not all volunteers came anywhere near to having these qualities, and some did not even aspire to having them, others, like Steffi, took it as their personal goal to measure up to expectations, sometimes at any cost. Steffi goes on:

Ich gebe prinzipiell immer alles. Diese Charaktereigenschaft brachte mich am Ende fast zu Fall. Das macht mich sehr angreifbar. Meine Erwartungen an mich selbst sind schon sehr hoch. Da ich diese meine eigenen Erwartungen und schon gar nicht die Erwartungen anderer enttäuschen will, gehe ich meistens über meine eigene Grenze hinaus. [Pia] wusste es auszunutzen.

In principle, I always give everything. This almost made me collapse at the end. It makes me very vulnerable. My expectations for myself are already very high. As I don't want to let myself down let alone anyone else, I mostly exceed my own limits. [Pia] knew to exploit this.

However, what Pia expects of her workawayers is not peculiar just to one person in the global periphery, but rather it comes from the globalised logic of entrepreneurialism, to which workawayers in the circumstances of the tourist resort had to adapt. Not only are qualities like self-reliance, independent initiative, goal-orientedness and readiness for action expected from actual entrepreneurs, but they also characterise the figure of the entrepreneurial self, the leitbild of neoliberal governmentality (cf. Bröckling 2007; Rose 1996; Kauppinen 2012). Thus also the host's expectations constitute a technology of subjectification whose significance extends far beyond a single Workaway exchange.

\subsection{Giving and receiving feedback after the exchange}

The Workaway exchange is not over as soon as the workawayer returns home. After that it is time to look back and give feedback. With every host profile on the Workaway.info site it is possible for both volunteers and hosts to rate the Workaway experience on a scale from poor to excellent and then to write a free evaluation. While the evaluations left by workawayers tend to be rather general descriptions of the exchange, the feedback left by hosts is more directly concerned with individual volunteers. Moreover, while the host is only called 'host' and there is no photograph to make him/her identifiable, workawayers appear with their own names accompanied by a profile photo. Positive evaluations are gathered in the Workaway Feedback Gallery, which is showcased directly on the main page Workaway Home. All evaluations are accessible to everyone visiting the site. 
Unfortunately, there are no feedback postings by Pia of workawayers who have stayed at her resort. There are two ratings by workawayers, rating the experience as 'poor', but no written feedback. A look at other feedback postings, however, left for instance by hosts running other tourist resorts in Lapland, gives insight into the nature of this practice. Much of the feedback is entirely personal, direct and painstakingly detailed evaluation (and criticism) not only of the (lack of) skills and competencies of the volunteers, but also of their attitudes, personal characteristics and occasional mood swings.

Apparently, these feedback practices are meant to give insight to potential workawayers and hosts into the experiences of 'real' hosts and volunteers. At the same time, however, they form a "democratized panopticon" (Bröckling 2007: 236), a system of mutual observation and evaluation. As such, these practices not only train the workawayer in the art of giving and taking feedback but they also prepare potential workawayers for being observed and evaluated down to the smallest detail of their performance, character and attitudes during their stay. In so doing, the Workaway feedback system works, like the ever denser network of similar practices, as grassroots training in the contemporary neoliberal evaluation culture, geared towards perpetual self-improvement (cf. Bröckling 2007: 236-247).

\section{Conclusions}

Volunteer tourism schemes such as Workaway are both symptomatic and constitutive of contemporary socio-economic developments, which make volunteer workers, and amongst them workawayers, subjects of contemporary globalisation in both senses of the expression. This paper has investigated the translocal formation of the figure of the workawayer through two main technologies of subjectification, the portal Workaway.info and the actuality of everyday work in a tourist resort in the far north of Lapland.

The study shows how the (prospective) workawayer is, on the one hand, is interpellated by a kind of non-capitalist cosmopolitan humanism with an emphasis on travel as a means of achieving intercultural understanding and contributing to a worthwhile cause. On the other hand, s/he gradually becomes not only attuned to but effectively trained in a variety of the practices and rationalities governing the contemporary neoliberalised world of work and, increasingly, the society as a whole. Thus the workawayer, a cultural adventurer, will acquire the skills needed in effective job applications and in organizing world-wide travel. Workawayers will be willing to embrace risk, while 
showing prudence (O’Malley 1996; Kauppinen 2012) and considering adequate measures for risk-management. Through everyday work they will learn to regard the customer as king and to flexibly adapt their actions and being to the customer's needs. As regards skills, workawayers become virtual all-rounders of the tourism industry, while as regards attitudes, they approximate to the entrepreneurial self, showing besides flexibility, risk-sensitivity and customerorientation, personal responsibility, goal-orientedness and readiness for action. They become accustomed to living in a "democratized panopticon" (Bröckling 2007) with ongoing evaluation and feedback as part of everyday life. Whatever they do, they do it seemingly of their own free will.

Although the Workaway initiative puts particular emphasis on the chances it offers to integrate into local cultures and immerse oneself in local languages, in a centre of globalised tourism these opportunities easily remain just a dream. Here, both access and the relationship to local languages and cultures are regulated by the rationality of business, in which languages figure as the means and cultures as the object of economic transactions. While local cultures gain value as a source of profit, local languages have little currency. What dominates is English, as the lingua franca of globalised tourism - and the globalised workplace (Angouri and Miglbauer 2014). If Workaway envisions multilingualism as part of a cosmopolitan subjectivity, as a key to promoting cultural understanding throughout the world, in the tourist resort languages are valued as one of the skills among others that are needed for running a business. Multilingualism, then, is not a key, but rather added value; what counts more is the ability to manage encounters ultimately 'without a language', or, with other semiotic means.

Of course, the mobile, cosmopolitan, multi-cultural individual envisioned by Workaway is a product and the goal not just of the humanist imagination but also of neoliberal globalisation (cf. Harvey 2009; see also Motobayashi and Dlaske et al. this volume). Feeding into the latter, the practice of travelling from country to country through the Workaway scheme, as many workawayers do, moulds volunteers into subjects who quickly adapt to new conditions, acquire new skills and, not least, get used to the idea of changing, temporary, short-term jobs. Despite the emphatic statement on the website, Workaway.info is NOT set up to provide cheap labour (Workaway information for hosts, no date), in the last analysis this is exactly what the workawayer, the cultural adventurer, becomes. By combining work and holiday, working holiday tourism, and Workaway as part of this trend, blurs the boundaries between leisure and work (cf. also Jarvis and Peel 2013; Duncan 2008). In the Workaway scheme, based on volunteering and promoted as "cultural exchange", work becomes part of cultural experience. The understanding of work as leisure is additionally reinforced by the (rather ironic) possibility of giving the Workaway experience 
as a gift. Hence, the Workaway scheme contributes not only to the 'economization of the social' (Bröckling et al. 2000), but also to the socialisation, or culturalisation, of the economic. In Workaway, the motivation for working is not money but, as portrayed by Workaway and workawayers themselves, a variety of other reasons such as personal development, solidarity and a desire to help. Notwithstanding the anti-capitalist ethos, this attitude towards work ties in neatly with the needs of the neoliberal order of work, and especially the growing scene of voluntarism, with their reliance on employees with commitment and inner motivation, on workers seeking to fulfill themselves (Rose 1996; 1999; Bröckling 2007; Kauppinen 2013; Baines 2004; Maes 2012). The Workaway scheme not only makes it possible to harness "the volunteer spirit" (Maes 2012) but also contributes to evoking it, thereby catering in the contemporary world rather for globalised capitalism than its counterforces. In the same vein, the nexus of voluntourism and the new economy examined here shows how investment by the state in the globalised governmentalities of neoliberal "structural development" (Heller 2011) can backfire: while Pia has taken the opportunity to set up her own business, she has also pushed the neoliberal logic beyond the interests of the state, in that by 'hiring' volunteers as workers she effectively avoids paying not only wages, but also taxes as part of the wages.

Although the workawayer has no gender in theory, in actual fact many of the governmental practices examined in this study are gendered. To a large extent this is because the gender divisions in Workaway jobs mimic the divisions in the actual job market, where women constitute the vast majority in the service sector (e.g. Lorente 2012). In consequence, volunteer work in the service sector under the Workaway scheme contributes not only to reproducing the gendered division of work, but also to shaping female subjects with the experience and (language) skills needed in the continuously globalising service industry.

\section{References}

Angouri, Jo \& Marlene Miglbauer. 2014. 'And then we summarise in English for the others': The lived experience of the multilingual workplace. Multilingua 33(1-2). 147-172.

Appadurai, Arjun. 1996. Modernity at large: Cultural dimensions of globalization. Minneapolis: University of Minnesota press.

Baines, Donna. 2004. Caring for nothing work organization and unwaged labour in social services. Work, Employment \& Society 18(2). 267-295.

Barakos, Elisabeth. 2015. Language policy and governmentality in businesses in Wales: a continuum of empowerment and regulation. Multilingua, DOI 10.1515/multi-2015-0007

Blommaert, Jan. 2005. Discourse. A critical introduction. Cambridge: Cambridge University Press. 
Bröckling, Ulrich. 2005. Gendering the enterprising self. Subjectification programs andgender differences in guides to success. Distinktion (11). 7-23.

Bröckling, Ulrich. 2007. Das unternehmerische Selbst. Soziologie einer Subjektivierungsform. Frankfurt am Main: Suhrkamp.

Bröckling, Ulrich, Susanne Krasmann \& Thomas Lemke (eds.). 2000. Gouvernementalität der Gegenwart. Studien zur Ökonomisierung des Sozialen. Frankfurt am Main: Suhrkamp.

Brown, Sally. 2005. Travelling with a purpose: Understanding the motives and benefits of volunteer vacationers. Current Issues in Tourism 8(6). 479-496.

Brown, Sally \& Alastair M. Morrison. 2003 Expanding volunteer vacation participation. An exploratory study on the mini-mission concept. Tourism Recreation Research 28(3). 73-82.

Clarke, Nick. 2004a. Free independent travelers? British working holiday makers in Australia. Transactions of the Institute of British Geographers 29(4). 499-509.

Clarke, Nick. 2004b. Mobility, fixity, agency: Australia's holiday working plan. Population, Space and Place 10. 411-420.

Coghlan, Alexandra. 2006. Volunteer tourism as an emerging trend or an expansion of ecotourism? A look a potential clients' perceptions of volunteer tourism organizations. International Journal of Nonprofit and Voluntary Sector Marketing 11(3). 225-237.

Coupland, Nikolas. 2010. Introduction: Sociolinguistics in the global era. In Nikolas Coupland (ed.), The Handbook of language and globalization, 1-27. Chichester: Wiley-Blackwell.

Dean, Mitchel. 2010. Governmentality. Power and rule in modern society. Los Angeles \& London: Sage.

Dlaske, Kati. 2014. Semiotics of pride and profit. Interrogating commodification in indigenous handicraft production. Social Semiotics 24(5). 582-598.

Dlaske, Kati. 2015. Discourse matters. Localness as a source of authenticity in craft businesses in peripheral minority language sites. Critical Approaches to Discourse Analysis across Disciplines 7(2). 243-262. Published ahead of issue at: http://www.lancaster.ac.uk/fass/ journals/cadaad/wp-content/uploads/2015/03/Volume-7_Dlaske.pdf

Dlaske, Kati, Elisabeth Barakos, Kyoko Motobayashi \& Mireille McLaughlin. 2015. Introduction to the special issue "Languaging the worker: Globalized governmentalities in/of language in peripheral spaces”. Multilingua.

Duncan, Tara. 2008. The internationalisation of tourism labour markets: Working and playing in a ski resort. In Tim Coles \& C. Michael Hall (eds.), International business and tourism: Global issues, contemporary interactions, 181-194. Oxon: Routledge.

Foucault, Michel. 1981. The history of sexuality. Vol 1: An introduction. Penguin: Harmondsworth.

Foucault, Michel. 1982. The subject and power. In Hubert L. Dreyfus \& Paul Rabinow (eds.), Michel Foucault. Beyond structuralism and hermeneutics, 208-226. Brighton: Harvester Press.

Harvey, David. 2009. Cosmopolitanism and the geographies of freedom. New York: Columbia University Press.

Haverig, Anika \& Steven Roberts. 2011. The New Zealand OE as governance through freedom: rethinking 'the apex of freedom'. Journal of Youth Studies 14(5). 587-603.

Heller, Monica. 2011. Paths to postnationalism: A critical ethnography of language and identity. New York: Oxford university press.

Heller, Monica \& Alexandre Duchêne. 2012. Changing discourses of language, capital and nation-state. In Monica Heller \& Alexandre Duchêne (eds.), Language in late capitalism. Pride and profit, 1-21. New York: Routledge. 
Heller, Monica, Joan Pujolar \& Alexandre Duchêne 2014. Linguistic commodification in tourism. Journal of Sociolinguistics 18(4). 539-566.

Inoue, Miyako. 2007. Language and gender in the age of neoliberalism. Gender \& Language. 1(1). 78-91.

Jarvis, Jeff \& Victoria Peel. 2013. Tourists for hire: International working holidaymakers in a work based destination in regional Australia. Tourism Management 37. 114-124.

Kauppinen, Kati. 2012. Subjects of Aspiration. Untersuchung von diskursiven Prozessen neoliberaler Regierung in einer postfeministischen Frauenzeitschrift. Finnische Beiträge zur Germanistik 28. Doctoral thesis. Frankfurt a. M.: Peter Lang.

Kauppinen, Kati. 2013. 'Full power despite stress': A discourse analytical examination of the interconnectedness of postfeminism and neoliberalism in the domain of work in an international women's magazine. Discourse \& Communication 7(2). 133-151.

Kauppinen, Kati. 2014. Welcome to the end of the world! Resignifying periphery under the new economy: A nexus analytical view of a tourist website. Journal of multicultural discourses 9(1). 1-19.

Lorente, Beatriz. 2012. The making of "Workers of the World": Language and the labor brokerage state. In Monica Heller \& Alexandre Duchêne (eds.), Language in late capitalism. Pride and profit, 183-206. New York: Routledge.

Maes, Kenneth. 2012. Volunteerism or labor exploitation? Harnessing the volunteer spirit to sustain AIDS treatment programs in urban Ethiopia. Human Organization 71(1). 54-64.

Motobayashi, Kyoko. 2015. Language teacher subjectivities in Japan's diaspora strategies: Teaching "my own language" as "someone's heritage language". Multilingua.

O’Malley, Pat. 1996. Risk and responsibility. In Andrew Barry, Thomas Osborne \& Nikolas Rose (eds.), Foucault and political reason. Liberalism, neo-liberalism and rationalities of government, 189-207, London: Routledge.

Pennycook, Alastair. 2010. Language as local practice. New York: Routledge.

Pietikäinen, Sari \& Kati Dlaske. 2013. Cutting across media spaces and boundaries: The case of a hybrid indigeneous Sámi comedy. Sociolinguistica 27. 87-100.

Pujolar, Joan \& Kathryn Jones. 2012. "Literary tourism: New appropriations of landscape and territory in Catalonia.” In Monica Heller \& Alexandre Duchêne (eds.), Language in late capitalism. Pride and profit, 93-115. New York: Routledge.

Rose, Nikolas. 1996. Inventing ourselves. Psychology, power and personhood. Cambridge: Cambridge University Press.

Rose, Nikolas. 1999. Governing the soul. The shaping of the private self. 2nd edn. London: Free Association Books.

Ruhanen, Lisa. 2010.Working while travelling: Tourism development opportunities for agricultural regions. Tourism 58(2). 173-184.

Scollon, Ron. 2005. Discourses of food in the world system. Toward a nexus analysis of a world problem. Journal of Language and Politics 4(3). 465-488.

Scollon Ron \& Suzie Wong Scollon 2004. Nexus analysis. Discourse and the emerging internet. London: Routledge.

Tomazos, K. \& Butler, R. 2009. Volunteer tourism: The new ecotourism? Anatolia 20(1): 196-212.

Tomazos, Kostas \&William Cooper. 2012. Volunteer tourism: At the crossroads of commercialisation and service? Current Issues in Tourism 15(5). 405-423.

Torabian, Pooneh \& Susan M. Arai. 2013. Tourist perceptions of souvenir authenticity: An exploration of selective tourist blogs. Current Issues in Tourism. http://dx.doi.org/ 10.1080/13683500.2013.820259, 1-16. 
TRAM. 2008. Volunteer tourism: A global analysis. Barcelona: ATLAS.

Urciuoli, Bonnie. 2008. Skills and selves in the new work place. American Ethnologist 35(2). 211-228.

Uriely, Natan. 2005. The tourist experience: Conceptual developments. Annals of Tourism Research 32(1). 199-216.

Urry, John. 2007. Mobilities. Cambridge: Polity.

Voswinkel, Stephan. 2004. Kundenorientierung. In Ulrich Bröckling, Susanne Krasmann \& Thomas Lemke (eds.), Glossar der Gegenwart. Frankfurt a.M.: Suhrkamp.

Workaway Home. http://www.workaway.info (accessed 15 September 2013).

Workaway hostlist. http://www.workaway.info/hostlist.html (accessed 15 September 2013). Workaway information for hosts. http://www.workaway.info/information-for-hosts.html (accessed 15 September 2013).

Workaway Information for travellers. http://www.workaway.info/information-for- travellers. html (accessed 15 September 2013).

Workaway Safety. http://www.workaway.info/safety.html (accessed 15 September 2013). 
Copyright of Multilingua is the property of De Gruyter and its content may not be copied or emailed to multiple sites or posted to a listserv without the copyright holder's express written permission. However, users may print, download, or email articles for individual use. 